\title{
Re-reading and rehabilitating Basil Bernstein
}

\author{
BROOK BOLANDER and RICHARD J. WATTS
}

\section{Abstract}

This article constitutes a re-reading of and an attempt to rehabilitate Basil Bernstein, both of which are important in light of the interpretation of Bernstein as a proponent of the verbal deficit view, and the general discrediting of his work on social class differences in the British educational system, as related to what he later called 'codes', by scholars like Jensen (1968) and Labov (1970), in particular. Exploring whether the international criticism of Bernstein was justified entails both an analysis of articles written by Jensen (1968) and Labov (1970) and by Bernstein, notably 'Language and social class' and 'A critique of the concept of compensatory education', both published in the first volume of Class, codes and control (Bernstein 1971). The article argues for the importance of contextualising Bernstein's thoughts on language and society within the socio-political climate framing his scholarship and the development of his ideas as a whole. We show that much of the interpretation of Bernstein is, in fact, a misinterpretation, for which Bernstein was only partly at fault. By rehabilitating some of Bernstein's ideas, it is possible to argue for their relevance today, especially with reference to salient connections between socio-cultural background and performance at school. Furthermore, Labov and Bernstein may not have been so far apart in their thinking as has previously been assumed.

Keywords: Labov, verbal deficit vs. verbal difference, compensatory education, (mis)interpretations of Bernstein

\section{Introduction}

Three years before his death in the year 2000, Bernstein published an article entitled 'Sociolinguistics: A personal view' (Bernstein 1997: 4352). In this article, he is concerned firstly to give his own personal evalu- 
ation of sociolinguistics and secondly to give a belated reply to Labov's criticism in 'The logic of nonstandard English' (1970). In the appendix to the article, he states the following:

It might be valuable from a historical point of view to take seriously Labov's paper, 'The Logic of Nonstandard English,' which seems to me to have lacked such attention. It has been enthusiastically reprinted but rarely analyzed in its own terms. Perhaps this exercise might shed some light on sociolinguistics.

(Bernstein 1997: 49)

The interesting word in this quotation is 'seriously', since it implies that Labov's influential paper has not hitherto been submitted to serious criticism. One of the effects of Labov's 1970 article was to discredit Bernstein's efforts to give what he, Bernstein, called a 'socio-linguistic' account of social class related educational problems in the British school system.

Our intention in this article is not to evaluate the 'seriousness' of Labov's article, nor to disagree essentially with its contents, but to try to ascertain whether Labov's criticism of Bernstein was really justified. While the two scholars were working within different disciplinary backgrounds and with educational systems revealing different kinds of inequalities, ${ }^{1}$ the problems confronting those societies were similar and are similar to a variety of educational inequalities that are still salient today (cf. Bolander this volume with respect to the situation in Switzerland; Martín Rojo et al. 2003 for the problems involving immigrants in the Spanish school system). If we are confronted with a continually recurring set of social problems within educational systems, ${ }^{2}$ the question remains as to whether, at least in this respect, Bernstein and Labov in the late 1960s were all that different from one another in their aims and beliefs, despite the fact that their methods were radically different.

To explore this question requires assessing Bernstein's stance on compensatory education and the validity of Labov's arguments with respect to reasons for the differential school achievement of children and adolescents from particular socio-economic and cultural groups. It is not enough to simply categorise the scholars as advocates of a verbal deficit or differences view, since this masks the real issue of why these perceptions have been socially constructed and what the effects of this construction are. However, since Bernstein has been associated with the former view (Linke 1991; Dittmar 1976; Jensen 1968; Oevermann 1972), and Labov with the latter (Neuland 1988; Linke 1991), the legitimacy of these interpretations needs to be addressed.

In order to describe the different approaches towards compensatory education in Great Britain and the USA, the second section of the article 
explores Bernstein's thoughts on this subject and highlights the importance of contextualising Bernstein's work in post-war Britain. It shows how Bernstein's thoughts on compensatory education, like many of the ideas he put forward, were dynamic and changed over time. This dynamism is particularly relevant since, as the leader of a research project on educational deficit financed by the then Ministry of Education in Britain in the 1960s, Bernstein moved from acquiescing in the design of programmes promoting partial compensatory education to criticizing compensatory education somewhat vehemently (see our discussion of a lecture held by Bernstein in New York in 1970, cf. section 2).

In the US Bernstein's ideas were apparently taken up in the early 1960 s by a group of educational psychologists (notably Bereiter, Engelmann, Jensen, Deutsch and Katz), who clearly interpreted him as proposing a deficit view as the source of educational underachievement for members of particular social classes in Britain and felt that 'many of his findings [were] probably valid among the lower and middle classes in America as well' (Jensen 1968: 118, emphasis added). This does not imply that Bernstein was a major figure in the move towards compensatory education in the US, but his association with the deficit view serves to suggest he was. The third section of the article exemplifies this by attempting to reconstruct the relationships between this particular school of American educational psychology and Bernstein's research, and hence to better appreciate a prime source of Labov's understanding of Bernstein.

In section 4 we then move to Labov's criticism of Bernstein in 'The logic of nonstandard English' (1970), where particular attention is paid to references to Bernstein. Paralleling the structure adopted in section 2, here, too, we argue for the importance of contextualising Labov's work, so as to show the different socio-political contexts framing the two scholars' work. At several points in Labov's article, statements are made that are reminiscent of Bernstein's thoughts. Despite the similarities, the article makes manifest the distance between the two scholars. Bernstein was partly to blame for the uptake of particular ideas and admits this when he states, '[c]learly, I must take some responsibility for these conflicting interpretations. The papers ${ }^{3}$ are obscure, lack precision and probably abound with ambiguities' (Bernstein 1971b: 19). Yet this distance was also partially constructed by virtue of how Bernstein's early work was interpreted. Hence, section five of the article contains an explanation of the notion of 'socio-linguistic code' (1971a), since the term code has been the source of so much misunderstanding of Bernstein's work (Bernstein 1971b; Atkinson 1985), and is at the centre of the schism between him and Labov. 
Both Labov and Bernstein see themselves as having different aims and beliefs, and this is also apparent in Bernstein's 'response' to Labov (1997). Yet they both argue that all schoolchildren should have access to the language of the educational system, which is - in both cases - a form of standard English. They also both maintain - more or less explicitly - that the language of the lower classes and socially disadvantaged cultural groups is not inferior in any intrinsic linguistic way, but rather that it is socially undervalued or even not valued.

Challenging inequalities in educational systems is still an important part of the social agenda today, even more so in light of a healthy interest in language ideologies. Language ideologies allow us to construct differences which are overtly and covertly linked to power (cf. Bourdieu 1991; see also Bourdieu on symbolic violence 1991: 209). The educational system is a part of state control over citizens and hence it is potentially contestable by those who are not in power. Language is significant in that it symbolically represents relationships of power that are played out in politically constructed social spaces; it is also the means by which such relationships can be challenged. Thus the final section of the article also addresses the role played by language in respect to those who are empowered and those who are disempowered and hence raises the perennial question of the status of standard language in opposition to nonstandard varieties.

\section{Bernstein's stance on compensatory education}

On googling Basil Bernstein on the Internet, we discovered two very different Wikipedia texts, one English and one German. The English text states that Bernstein 'was a British sociologist and linguist, known for his work in the sociology of education'. We are sure that Bernstein would have modestly challenged the claim that he was a linguist, but at least there is no reference here to him having anything to do with a verbal deficit view. The whole of the article on Bernstein displays a sound knowledge of his work, not just of the theory of codes, and neither 'deficit theory' nor 'compensatory education' is ever mentioned.

The German Wikipedia text, on the other hand, is just two sentences long: 'Basil Bernstein stellte in den 1960-er Jahren die Defizithypothese in der Soziolinguistik auf. Er stellte die Theorie auf, dass die Sprache der Unterschicht defizitär gegenüber der Sprache der Mittelschicht sei' ['Basil Bernstein set up the deficit hypothesis in sociolinguistics during the 1960s. He set up the theory that the language of the lower classes was deficient when compared with the language of the middle class']. We can interpret the text as suggesting that Bernstein is understood in Germany as being not only a supporter of what is known as the verbal deficit 
view but even as its creator. A close look at the work of Ulrich Oevermann and Norbert Dittmar in the early 1970s confirms this interpretation of Bernstein's work.

The differences between the two texts reveal very different interpretations of Bernstein's work. Our reading of Bernstein shows the importance of contextualising the development of his ideas against the sociological, political and educational background of post-war Britain in the 1950s and 1960s before looking at Bernstein's stance on compensatory education in more detail.

\subsection{Contextualising Bernstein}

In post-war Britain of the 1950s and early 1960s the major social problems confronting the country were how to rebuild industry and revitalise the economy to reach pre-war levels of production; how to find enough manpower to make this work; how to deal with an increasingly unwieldy colonial empire; and how to rebuild the education system in an environment in which the old divisions into social classes, reaching as far back as the early $18^{\text {th }}$ century (cf. Watts 2003: chapter 2 ), no longer seemed to work.

The manpower problem was partially solved by encouraging the immigration into Britain of colonial subjects, who were of course technically British. The majority of these came first from the West Indies and then from the new states emerging out of the Indian Empire after gaining its independence in 1947 (India, Pakistan and Sri Lanka [formerly Ceylon]). We stress the word 'partially' in this context as the major problem of rebuilding industry led to the gradual breakdown over time of such nationalised heavy industries as ship-building, shipping, steel and coal-mining, and the consequent redundancy of many of the immigrants working in those industries. During the 1950s and 1960s there was a considerable amount of industrial unrest due to attempts to institute a so-called colour-bar to prevent 'coloured' immigrants from the West Indies and Southern Asia from being employed. However, the overall number of immigrants hardly constituted a demographic 'problem'.

The major social problem was without doubt the breakdown of the social class system, or rather the realisation that an insistence on social class membership constituted a hindrance to the class mobility and permeability that would be necessary to build the 'new Britain'. The major obstacle here was perceived in socialist circles to be the school system. As long as the Conservative Party was in power from 1951 until 1964 the old breakdown was retained between the traditional 'public schools', which were anything but public, and state schools; within the latter system a distinction was upheld on the secondary level after 11 years of 
age between grammar schools and secondary modern schools. When the Labour Party came into office in 1964, the school system in the state sector was turned upside down. This is not the place to go into details, but from the point of view of the teaching of English (and it was recognised that the teaching of any subject, unfortunately including foreign languages, should be carried out in English) a minor revolution took place. Formal grammar teaching suddenly became obsolete, and the stress was laid on self-expression, creativity, imagination and communication. In the late 1980s and early 1990s there was an attempt to undo the effects of this revolution by the Conservative Thatcher government through the reintroduction of formal grammar teaching (see many of the articles in Bex \& Watts 1999), but without much success.

It was into this underlying ferment of activity and dissent that Bernstein found himself projected after passing the post-graduate certificate in education and being appointed to the City Day College in 1954 (see the 'Introduction' to volume 1 of Codes, Class and Control 1971). The description that Bernstein gives of his experiences at the College is one of the most illuminating passages in his whole work, and the 'Introduction' is omitted at any researcher's peril. The new stress on values such as creativity and imagination which emerged in the Comprehensive systems of education in the second half of the 1960s is evident in Bernstein's own teaching ten years prior to its introduction, as we see in the following quotation from Bernstein:

One day I took a piece of a student's continuous writing and broke it up into its constituent sentences and arranged the sentences hierarchically on the page, so that it looked like a poem. The piece took on a new and vital life. The gaps between the lines were full of meaning. I took a Bob Dylan ballad and produced a second version in which the lines were arranged continuously as in prose. I invited the students to read both versions. I then asked whether they felt there was any difference between the two versions. Yes, there was a difference. Poetry among other things has something to do with the hierarchical, and so spatial, ordering of lines. The space between the lines, the interval, allowed the sentences to reverberate against each other. The space between the lines was the listener or reader's space out of which he [sic] created a unique, unspoken, personal meaning.

(1971: 5-6, emphasis in original)

We shall argue that the major feature of a restricted sociolinguistic code has nothing to do with deficit but has a great deal to do with these 'unique, unspoken meanings' (cf. section 5). When dealing with terms 
such as 'deficit', 'compensatory', etc. we need to remember both this situation in post-war Britain and Bernstein's personal engagement with it.

\subsection{On deficit and compensatory education in Bernstein}

The first volume of Codes, class and control, which appeared in 1971, contains no reference at all to the words 'deficit' or 'deficient'. 'Deprivation' occurs 5 times, all of which are in Chapter 10, which is the published version of a paper given at the Work Conference of the Teachers College, Columbia University in New York in 1970 (the same year in which Labov published 'The logic of non-standard English') with the title 'A critique of the concept of Compensatory Education'. This is also the title of Chapter 10 in volume 1 of Class, codes and control. In this section we intend to spend some time looking at this chapter and also at the Foreword and Postcript of D. M. and G. A. Gahagan's (1970) book Talk reform: Explorations in language for infant school children, both of which were written by Basil Bernstein.

In the 'Introduction' to the first volume of Class, Codes and Control, Bernstein relates, in some detail, the genesis of the research project set up in 1963 at the Sociological Research Unit of the Institute of Education at London University, of which he was made director. Bernstein first submitted an ambitious research proposal to the Department of Education (as the government ministry was then called). The original aim of the project was to investigate the effects of socialisation in families of different social backgrounds (working- and middle-class) on the 'children's use of speech in different contexts' (1971: 10). His ultimate goal was to test the validity of his theory of sociolinguistic codes and 'to examine the conditions for change of code' (1971: 10). However, the Department of Education evaluated the proposal as being 'too academic' and wanted him 'to design a programme for infant school children which would enhance their contextual use of speech' (1971: 10). Bernstein describes how uneasy he was about accepting the terms laid down by the Department of Education, and he makes the following pertinent observation:

From that point on until the conclusion of the research, I was haunted by the problems of the language programme, its implications and possible deleterious outcomes. For the programme was no academic puzzle; it involved children. I also saw that the sampling procedure for the whole research necessarily would be dictated by an experimental design required to evaluate the effects, if any, of the language programme. The tail would wag - and indeed, did wag not very comfortably - the research dog.

(Bernstein 1971: 10) 
The fact of the matter was that the Department of Education, not Bernstein himself, wished to experiment with a form of 'compensatory education'. In 1964, in an attempt to satisfy the Department of Education's desire to apply the theory to a practical compensatory teaching programme, two educational psychologists, Georgina and Denis Gahagan, were taken onto the research team. In the 'Foreword' to the Gahagans' book Bernstein takes great pains to stress his misgivings with regard to the projected teaching programme, which was designed for primary schools in a working-class area of East London. He suggests that the programme 'was set up under conditions that were far from ideal' and insists that '[i]t constituted only a small part of the total research effort under my direction' (Bernstein 1970a: vii). He is absolutely clear about the reasons for his anxiety:

I was also uneasy about the methodological consequence of running such a programme in an area which was already marked out for other (more distinctly sociological) enquiries.

(ibid.: vii)

And he stresses that the 'officials of the then Ministry of Education ... were extremely anxious to see a trial language programme implemented' (ibid.: vii). The programme itself was limited to just twenty minutes a day; it was in no way a full-scale attempt at introducing compensatory teaching. This shows that while Bernstein was involved in the research project itself, he was not in favour of compensatory education and thus did not endorse a deficit view of language. At the very end of this postscript he gives the following unequivocal answer to all those who have associated him - wrongly, we insist - with having fostered a notion of linguistic deficit and having argued that working-class children suffer from "linguistic or cultural deprivation":

My own view has always been that code restriction where it exists does not constitute linguistic or cultural deprivation; for there is a delicacy and variety in cultural and imaginative forms [our italics]. I can understand, however, that from a specific psychological viewpoint code restrictions may be equated with educational [our italics] deficit. That there is an educational issue I do not deny, but that is why we have schools. The schools' central task as I see it is to offer all [italics in the original] children the possibility of exploring the boundaries of man's consciousness in such a way that the boundaries are not experienced as a prison, but as a tension between the known and the possible.

(Bernstein 1970b: 117)

The ironic point about this quotation is that Bernstein's mention of the 'delicacy and variety in cultural and imaginative forms' in working-class 
children is exactly what Labov (1970) attempts to display within the language of young Afro-American English speakers in New York.

Before we explore the different means by which Bernstein's research findings found their way into the work of American educational psychologists of the 1960s (and, incidentally, German 'sociolinguists' of the 1970s), we first need to take a closer look at the 1970 lecture, in which he most clearly dissociates himself from the notion of 'compensatory education'. At the beginning of the talk delivered to the Work Conference of the Teachers College, Columbia University in 1970, Bernstein outlines why it is psychologists rather than sociologists who were interested in educational problems in both the US and the UK after the Second World War. He points out that one University Department of Education and a number of Colleges of Education in Britain had instituted advanced courses in compensatory education (Bernstein 1971: 191) by the time the first volume of Codes, class and control went to press in 1971, although he does not name them. He finds it somewhat odd that his own writings 'have sometimes been used (and more often abused) to highlight aspects of the general problems and dilemmas' (1971: 191). ${ }^{4}$ Our guess is that an inadequate explanation of exactly how the term 'sociolinguistic code', and in particular the terms 'restricted code' and 'elaborated code', should be properly understood is the reason for this 'abuse', and we will demonstrate how Bernstein intended them to be understood (as well as how they were generally misunderstood) in section 5 of this paper by quoting directly from Bernstein's work.

One of the general problems facing schools in Britain in the 1960s was the fact that ' 79 percent of all secondary modern schools in slum and problem areas were materially grossly inadequate' (ibid.) and that their turnover of teaching staff was very high, obviously leading to a lack of continuity in teaching abilities as well as teaching methods. Bernstein takes his data from the Newsome Report of 1963, and he makes the following very relevant comment:

I do not understand how we can talk about offering compensatory education to children who, in the first place, have as yet not been offered an adequate educational environment.

(ibid.)

His conclusion is that " $[\mathrm{t}]$ he concept "compensatory education" serves to direct attention away from the internal organization and the educational context of the school, and focus our attention on the families and children' (1971: 192). The result of this refocusing of attention is that, rather than the inadequate financing of educational institutions and the difficult staffing situation being interpreted as the root causes of the problems, educational psychologists construct the children themselves as 'lit- 
tle deficit systems' (ibid.). His criticism of this tendency to transfer attention from social factors to presumed psychological deficiencies in the child is summed up in the following quotation, which makes it more than difficult to attribute support of 'compensatory education' to Bernstein:

$\mathrm{We}^{5}$ take one group of children whom [sic] we know beforehand possess attributes favourable to school achievement, and a second group of children whom we know beforehand lack these attributes. Then we evaluate one group in terms of what it lacks when compared with another. In this way research, unwittingly, underscores the notion of deficit and confirms the status quo of a given organization, transmission and, in particular, evaluation of knowledge.

(1971: 193, italics in the original)

Bernstein then attributes this movement in no small measure to a misunderstanding of his own work on sociolinguistic codes, and points out that the concept 'restricted code' 'has been equated with "linguistic deprivation", or even with the non-verbal child' (1971: 194). However, even though Bernstein states quite clearly that working-class mothers are not non-verbal but 'only that they differ from middle-class mothers in the contexts which evoke universalistic meanings' and thus that they are 'not linguistically deprived, neither are their children' (1971: 196), he follows this statement with a rather confused explanation of sociolinguistic codes in which notions such as 'universalistic meanings' and 'particularistic orders of meanings' are introduced without giving any definition of the terms. This only increases confusion, and it does not help much when he points out two pages later that ' $[t]$ he concept code refers to the transmission of the deep meaning structure of a culture or sub-culture: the basic interpretative rules' (1971: 198).

Clarity returns one page later when Bernstein unequivocally states the following:

Now because the sub-culture through its forms of social integration generates a restricted code, it does not mean that the resultant speech and meaning system is linguistically or culturally deprived, that the children have nothing to offer the school, that their imaginings are not significant. Nor does it mean that we have to teach the children formal grammar. Nor does it mean that we have to interfere with their dialect. There is nothing, but nothing, in the dialect as such, which prevents a child from internalizing and learning to use universalistic meanings. But if the contents of learning, the examples, the reading books, are not contexts which are triggers for the children's imaginings, are not triggers on the children's curiosity and explorations in 
his [sic] family and community, then the child is not at home in the educational world.

(1971: 199)

It is truly hard to believe that Labov should have so misread Bernstein, but simply taken the interpretations of Bernstein's work that had filtered through to American educational psychologists like Bereiter, Engelmann, Jensen, Deutsch and Katz at face value. We recognise the same anxieties about the educational chances of underprivileged sections of society and the same anger at their discrimination at the hands of deficit theorists and the practitioners of compensatory education as those which run like a red thread through Labov's 'The logic of nonstandard English'. For this reason it is necessary to trace the appropriation and misinterpretation of Bernstein's early work in the work of those psychologists. Since this would clearly go beyond the bounds of the present article, we shall restrict ourselves in the next section to a discussion of Arthur R. Jensen's chapter on 'Social class and verbal learning' in Social class, race, and psychological development edited by Deutsch, Katz and Jensen (1968).

\section{Relationships between Bernstein's research and the 'deficit' school of American educational psychology}

The principal articles by Bernstein that inspired the interest of educational psychologists in the USA were all from the early 1960s. Jensen makes reference to 'Language and social class' which appeared in the British Journal of Sociology in 1960, but, as we shall see, there is a distinct hint that he was familiar with Bernstein's 1959 article in the same journal entitled 'A public language: some sociological implications of a linguistic form'. ${ }^{6}$ In the 1959 article Bernstein begins to explore the connections between language and under-achievement in education, and he considers what he calls 'public language' to '[facilitate] thinking of a descriptive order and sensitivity to a particular form of social interaction' (1971: 42). According to Bernstein, a public language turns out to be typical of 'the unskilled and semi-skilled strata' of the population (ibid.). Unfortunately, he then gives a list of the characteristics of a public language, which turn out to be largely surface structure features described in a non-linguistic evaluative way (e.g. '[r]igid and limited use of adjectives and adverbs', '[s] hort, grammatically simple, often unfinished sentences', etc. [ibid.]). In the notes section we find a list of the features of what he calls a 'formal language', which contains equally evaluative descriptions such as '[a]ccurate grammatical order and syntax', '[1]ogical modifications and stress', etc. (Bernstein 1971: 55). Bernstein admits in the first volume of Codes, Class and Control that his knowledge of linguistics at this early stage in his career was extremely rudimentary, which 
is obvious on reading these features. The expression 'linguistic forms' turns out to refer to a set of normative, prescriptive opposing categories, setting off what appear, at this stage in his work, to be 'standard' forms of language (formal language) and non-standard forms (public language) (cf. the discussion in section 6). And as we might expect, the positive side of the evaluation lies with the 'standard' forms. However, it would be unwise to ignore the following important statements in the 1959 article:

Language is considered one of the most important means of initiating, synthesizing, and reinforcing ways of thinking, feeling and behaviour which are functionally related to the social group. It does not, of itself, prevent the expression of specific ideas or confine the individual to a given level of conceptualization, but certain ideas and generalizations are facilitated rather than others.

It is all too easy to infer from the close juxtaposition of the list of characteristics of 'public language' and what he says in the above quotation that 'public language' reinforces ways of 'thinking, feeling and behaviour' that are in some measure substandard and deficient in not allowing access to the dominant discursive practices of the classroom. However, we feel the need at this point to stress once again the fact that Bernstein's ideas are continually evolving throughout his work. Taken on its own, the above quotation simply stresses a verbal differences rather than a verbal deficit point of view (cf. the interpretation of Labov's 'The logic of non-standard English' and the, in our opinion, erroneous interpretation of Bernstein as presenting a theory of language deficit), and it was this difference that Bernstein continued to explore throughout the 1960s. We have here the seeds of what Bernstein began to call 'linguistic codes' in 1962 and ended up at the end of the decade calling 'socio-linguistic codes'.

Having looked at the article (Bernstein 1959) Jensen and his associates probably read, we now turn to the research note (i.e. Bernstein 1960) Jensen (1968) explicitly refers to. The ideas presented in 'Language and social class' published in 1960 in the British Journal of Sociology were certainly taken up by educational psychologists in the USA, who came to believe in a class-determined language deficit leading to an intelligence deficit. As we shall shortly see, the class deficit quickly turned into a race deficit in their writings, in that most of their research was carried out not on working-class whites but on Afro-Americans.

In the 1960 article Bernstein reports on an experiment devised to discover whether, in terms of linguistic structures used, the results of a discussion on the abolition of the death penalty (a very controversial 
topic in the Britain of the early 1960s) held with working-class students of a day-release college in the East End and with students at one of the major public schools could be correlated with the results of a test designed to measure non-verbal intelligence (Raven's Progressive Matrices). The very assumption underlying this experiment would appear to be that the public school students would show a higher level of verbal intelligence than the day-release college students (where subjects had been matched for non-verbal intelligence) and that this would somehow have to do with the distinction between public and formal language. From our present-day point of view, such an assumption appears extremely tendentious. There were indeed significant correlations, but Bernstein is at pains to point out that there is no way of knowing whether the correlation may have been between language use and potential intelligence or language use and developed intelligence (1971: 66), although he does not define these two terms. In addition, the great danger in setting up correlations is to automatically assume a causal relationship between the two variables, i.e. that what was later referred to as a 'restricted code' causes a deficit in some form of intelligence. Although there is always a possibility that it is the indicator of such a causal relationship, statistics of this kind in no way provide incontrovertible evidence of such an interpretation. Our interpretation is that Bernstein was more interested in showing that there was no link between non-verbal intelligence and class, but between verbal intelligence and class. The implication here is that certain children with a certain style of language performance are seen as being less intelligent in accordance with such tests.

Bernstein's conclusion is hedged somewhat, indicating that he was aware of the dangers of interpreting correlations in this way:

Either the mode of expression of intelligence is a cultural function or the lower working-class are genetically deficient in a factor which enables the exploitation of complex verbal relationships. The latter possibility seems improbable especially when one considers that the normal linguistic environment of the working class is one of relative deprivation. It is thought that the mode of expression of intelligence ... may well be a matter of learning: in particular the early learning of speech forms, which create and reinforce in the user different dimensions of significance.

(1971: 66, emphasis in original)

Not being a psychologist, Bernstein is loath to admit of a genetic deficiency in the lower working classes which somehow prevents them from acquiring the ability to exploit 'complex verbal relationships'. He hedges quite significantly in this passage, but we can clearly infer that the 'rela- 
tive deprivation' referred to in relation to working-class language users is not a linguistic deprivation at all, but rather something that is socioculturally learned, i.e. it is not a question of intelligence but one of the expressions of intelligence.

Jensen picks up the issue of intelligence from Bernstein (1960) without contextualizing Bernstein's argument about intelligence in the research note as a whole. Jensen's chapter reports on differences in verbal ability - which he calls 'verbal learning' - between lower class and middle class children and experiments carried out at the level of kindergarten. The ultimate goal is to suggest an educational application of the research which would avoid 'the wasteful inefficiency of the well-meaning, but haphazard, shotgun approach that has characterized so much of the educational effort in the field so far' (1968: 165). The application would aim to improve 'the educational potential of lower-class children' by devising 'training [sic] procedures' that would enable lower-class children to develop the linguistic ability to acquire 'any new subject matter reading, arithmetic, and other school subjects involving complex discriminations and mediational processes' (1968: 166). If Jensen envisages this linguistic ability as representing the characteristics of formal language set up by Bernstein in his 1959 article, the 'training procedures' advocated would have the effect of shifting users of non-standard varieties of language to some version of the 'standard'. It is precisely this shift against which Labov argues in 'The logic of non-standard English', in which he provides evidence that non-standard varieties of English, in particular AAVE, are no less logical than standard varieties.

But how does Bernstein fit into this equation? Firstly, Jensen (and other American educational psychologists who espouse the verbal deficit argument) suggests, like Bernstein, that there are observable differences in the kind of language produced by working-class and middle-class children. However, he suggests that these 'social class differences in "language" ... arouse notions about the middle-class social advantages of "correct" pronunciation, "good" English, avoidance of slang, and so forth' (1968: 116) which are then related directly to language development. Thus language development implies acquiring 'correct pronunciation', 'good English' and avoiding 'slang', a term which is never defined but which consistently carries with it, on both sides of the Atlantic, a heavy negative evaluative load. Two pages further on in the chapter he introduces Bernstein:

Most of the research on social-class differences in verbal behavior has been carried on in England by sociologist Basil Bernstein (1960), but many of his findings are probably valid among the lower and middle classes in America as well.

(1968: 118, our emphasis) 
Bernstein's unwillingness to accept that lower working-class speakers have a genetic deficiency and his strong implication that we are faced with a socio-cultural deficit ${ }^{7}$ rather than a linguistic deficit, which effectively negates any causal link between language and intelligence, are simply ignored by Jensen. Indeed, lower down in the same paragraph he makes the statement that ' $[\mathrm{m}] \mathrm{uch}$ of lower-class language consists of a kind of incidental "emotional" accompaniment to action here and now'. He then states the following:

Thus middle-class language is more abstract and necessarily somewhat more flexible, detailed and subtle in its descriptive aspects. In all social classes, conversational language serves mainly as a social lubricant, but in the lower class the expository function of language is relatively less prominent than in the middle class. These differences are important for psychological development because of the intimate relationship between language and thought. It would be a mistake to think of language as merely a vehicle for thought; developmentally and functionally both are completely interdependent.

(1968: 119)

This quotation inspires a gamut of questions. How are we to interpret the statement that middle-class language is "necessarily more flexible, detailed and subtle in its descriptive aspects'? Is this simply because middle-class language is, obviously, spoken by middle-class speakers so that being a middle-class speaker immediately places one into a position of superiority? And why 'necessarily'? At a time when conversation analysis was just taking off, how can Jensen maintain that conversation is nothing more than a social lubricant? And what are we to make of the final two sentences? It is clear to us that Jensen is effectively implying that lower-class speakers with 'deficient' language thus have deficient thoughts. None of this would have been endorsed by Bernstein, and it is hardly surprising that he considered his ideas to have been abused rather than used by this school of American educational psychologists.

The plot thickens later in the article when Jensen refers to work by Milner (1951) on AAVE children, whom Jensen in 1968 still insists on calling 'Negro'. Lower-class speakers are thus, at least implicitly, to be equated with AAVE speakers, which leads to the conclusion that AAVE is a deficient non-standard variety of English, and that AAVE speakers cannot use language abstractly, nor can they be flexible, detailed and subtle in their use of language. Not only is this problematic because Jensen bases his interpretation on Bernstein and the argument that his findings 'are probably valid among the lower and middle classes in America as well' (Jensen 1968: 118), but it is also problematic because 
Labov also assumes that the view 'that lower-class black children have no language at all' (Labov 1970: 4) emanates directly from Bernstein. While Labov is correct in reacting to the deficit view being put forward by this group of American educational psychologists, it is unfortunate that in doing so he drew Bernstein into the circle of language deficit theorists and supporters of compensatory education, as we shall see in the following section.

\section{Labov's criticism of Bernstein}

If, to quote Bernstein (1997: 49), we wish 'to take seriously Labov's paper, "The Logic of Nonstandard English"', it is necessary to situate Labov (1970) within its proper socio-historical context.

\subsection{Contextualising Labov}

The 1960s were also a time of social ferment in the USA, but for quite different reasons than in Britain. The election of John F. Kennedy as President in 1960 heralded an era of optimism for the Afro-American Civil Rights Movement, which had been in existence since 1894 but became particularly active in a non-violent way in 1955. Racial segregation and discrimination, particularly in the schools, was still rife in the Southern States, and Afro-Americans were also prevented by force from exercising their right to vote throughout the South. The Kennedy administration quickly came to realise the need for a Civil Rights Act, which was championed actively by the president's brother and justice minister Robert F. Kennedy, and enjoyed the support of the Afro-American leader of the Civil Rights movement, the Rev. Martin Luther King. The bill was debated in 1964 and finally signed by President Lyndon B. Johnson on July 2, 1964.

The title of the act is as follows:

An Act to enforce the constitutional right to vote, to confer jurisdiction upon the district courts of the United States to provide relief against discrimination in public accommodations, to authorize the Attorney General to institute suits to protect constitutional rights in public facilities and public education, to extend the Commission on Civil Rights, to prevent discrimination in federally assisted programs, to establish a Commission on Equal Employment Opportunity, and for other purposes.

(http://www.ourdocuments.gov/doc.php?flash $=$ true $\&$ doc $=97$ accessed 18.12.08) 
The main goal of the Act was to put a stop to any form of racial segregation and discrimination and to guarantee voting rights for non-white Americans throughout the USA. The problems in the educational systems of the USA had been racial segregation throughout the Southern States prior to 1964 and low educational achievement of Afro-Americans compared to white Americans in areas where segregation was either illegal or not practised.

The Bereiter/Engelmann pre-school compensatory education programme was set up on the grounds that a strong correlation had been found in young Afro-American first graders between intelligence and language use. Although it was never stated in as many words, the tenor of the research was that Afro-Americans were less intelligent than white Americans on the basis of the difference between their form of English and that of their white colleagues. As Labov $(1970,1972 b)$ indicates, the assumption here seemed to be that "Negro children must have a language with which they can learn ... and these children come to school without such a language" (1970: 4). Bereiter had reported from his empirical investigation of four-year-old children in Urbana that "their communication was by gestures", "single words", and "a series of badlyconnected words and phrases", such as They mine and Me got juice' (ibid., emphasis in the original).

At the time Labov was involved in the final stages of research into 'the vernacular language of south-central Harlem and the standard English of the classroom' (1972a: xiv) which was to be reported on in Language in the inner city (1972a). As he further reports in the 'Introduction' to that book, the reading difficulties which gave rise to the research projects granted by the Office of Education in New York City led to a full description of the linguistic system that he called at that point in time 'Black English Vernacular' and to the realisation that 'the major causes of reading failure are political and cultural conflicts in the classroom, and dialect differences are important because they are symbols of this conflict' (1972a: xiv). The reader is asked to recall the following statement by Bernstein in his trenchant critique of compensatory education delivered as a lecture in New York in 1970: '.. if the contents of learning, the examples, the reading books, are not contexts which are triggers for the children's imaginings, are not triggers on the children's curiosity and explorations in his family and community, then the child is not at home in the educational world.' Apart from the fact that, for Labov, the reading failure of Afro-American children is attributed to 'political and cultural conflicts in the classroom' - which, within the political climate of the 1960s in the USA, is perfectly understandable we fail to see any real difference here between Labov's argument and Bernstein's. 


\subsection{On Labov on Bernstein}

In 'The logic of non-standard English' (1970) and in 'Academic ignorance and Black intelligence' (1972b), Basil Bernstein's writings are held responsible for influencing the work of Bereiter, Engelmann, Deutsch, Katz and Jensen. Labov first identifies 'the most extreme view' of this school of thought - that 'lower-class Negro children have no language at all' (1970: 4). Given the attenuated political climate of the 1960s in the USA, such a view must have been a veritable thorn in the flesh of Civil Rights activists. In the very next sentence, however, we read the following:

The notion is first drawn from Basil Bernstein's writings that 'much of lower-class language consists of a kind of incidental "emotional" accompaniment to action here and now'. (Jensen 1968: 118) (1970:4)

We are willing to accept the argument that Labov was not implying that Bernstein himself had had anything to say about the language of 'lowerclass Negro children', but the juxtaposition of the two sentences certainly leaves that interpretation open. The following sentence is also similarly ambiguous:

Bernstein's views are filtered through a strong bias against all forms of working-class behavior, so that middle-class language is seen as superior in every respect - as 'more abstract, and necessarily somewhat more flexible, detailed and subtle'.

(ibid.)

Once again, those who support pre-school compensatory education can be interpreted as having 'a strong bias against all forms of working-class behavior', but, from Labov's text, it is at least possible to take Bernstein as also having held that bias. Bernstein grew up in an immigrant Jewish family in the East End of London and must have known all about the vicissitudes of growing up and going to school as members of the working class in pre- and post-war East London. He was also employed in the immediate post-war years as a resident worker in the Bernhard Baron Settlement in Stepney, and, as we have seen, he taught working-class Post Office messenger boys at the City Day College. So any implication that Bernstein had such a bias appears to us to be nothing short of ludicrous. The crux of the matter lies, unfortunately, in a misunderstanding of Bernstein's two 'sociolinguistic' codes, restricted and elaborated. Labov states that '[Bereiter] identifies their speech [i.e. the speech of lower-class Negro children] with his interpretation of Bernstein's restricted code: "the language of culturally deprived children ... is not 
merely an underdeveloped version of standard English, but is a basically non-logical mode of expressive behaviour" (Bereiter et al. 1966: 113)' (1970: 4-5).

It is incumbent on us in section 5 to clarify what Bernstein really meant by the term 'code'. This is particularly important since Labov questions whether an elaborated code is 'not simply an elaborated style, rather than a superior code or system' (Labov 1970: 12). While Labov recognises that ' $[\mathrm{n}] \mathrm{o}$ rules or detailed descriptions of the operation of such codes are provided as yet, so that this central concept remains to be specified' (Labov 1970: 36, endnote 10), the above section made manifest Labov's reliance on Jensen, who felt he had a clear understanding of what Bernstein meant.

\section{Bernstein's notion of 'socio-linguistic code'}

On the first page to his introduction to Class, codes and control volume 1, Bernstein states the following:

Each paper is an attempt to come to terms with an obstinate idea in me which I could neither give up nor properly understand. I always felt the only paper worth reading was the next one to be written.

Indeed, for almost half a century Bernstein was concerned with different aspects of the relationship between language and social class. Publications spanning the time period from 1958 to 1990 (the year in which the fourth volume of Class, codes and control was published) saw Bernstein develop his ideas. There are a variety of factors that need to be considered when reading individual papers by Bernstein, for example the following:

- the volume of material he produced

- the time period during which he produced it

- the classification of his own work as ongoing

- the lack of a comprehensive summary by Bernstein on his work, and

- the presence of ambiguities and confusion in some of the papers (as pointed out by Bernstein 1971: 19)

Depending on the paper one reads, it is possible to derive various (at times incompatible) interpretations of Bernstein. The development and shift of Bernstein's thoughts regarding compensatory education (cf. section 2) are a case in point.

Bernstein's conceptualisation of the role played by language also changes over time. It is in his first volume of Class, codes and control 
that Bernstein focuses on language, specifically on 'research into sociolinguistic codes' (Bernstein 1971: 237). The papers in the first volume cover the time period from 1958 to 1971 and constitute a progressive attempt to grasp the role played by language in the family, and its implications for a child's success at school. Beginning with an understanding of language in terms of differential 'speech modes', which primarily relate to the emphasis placed on language in the family (cf. Bolander this volume), during the period 1958-1961 Bernstein attempts to grasp the connection between class and language as being related to differential uses of linguistic structures in the two family types. As we saw in section 3, using the terms public and formal language, Bernstein compiled a list of features, ten for public language and eight for formal language, that one would expect to find in a working-class family (public language) and a middle-class family (formal language). He also introduces a key distinction between 'implicit' and 'explicit' in relation to the two language types. While this distinction remains important throughout Bernstein's work, the introduction of the concept 'code' signified an attempt to move away from describing features of language, to looking at how language (specifically codes) plays a role in a child's orientation to meaning in social context. The concept of 'code' is part of an attempt to understand the semiosis of social behaviour, which obviously involves language.

Evidence of this shift to looking at 'code' from a social semiotic point of view ${ }^{8}$ can be found in an article entitled 'Social class, codes and communication' (1987), in which Bernstein describes the descriptive features as 'unreliable'. He also states the following, which is of relevance with respect to the uptake of his work in the US in particular:

I certainly would not wish to defend indicators of what was called then 'public language use' but would argue emphatically that it was made abundantly clear and stated that such a framework of communication should not be confused with dialect ..., that in my terms all languages and their varieties carried the same potential for producing either of the associated speech forms ....

(Bernstein 1987: 564, emphasis added)

This notion of varieties carrying the same potential for producing either speech forms is important, since it is what Bernstein attempts to make explicitly manifest through his concept of 'code'. Yet articles in which Bernstein is mentioned (cf. section 3) were written before the introduction of the code concept. As pointed out in section 3, educational psychologists in the USA drew upon Bernstein (1960) and possibly Bernstein (1959). There is no direct evidence that they have looked at later 
work of Bernstein's, i.e. work in which he introduces and develops the concept of 'code'.

Thus it is not possible to know where their interpretation of 'code' came from. It may have come from the reading of texts by Bernstein published after the introduction of code, yet before the publication of Jensen (1968) and Labov (1970). These could include:" 'Linguistic codes, hesitation phenomena and intelligence' (originally published in Language and Speech 5 in 1962), 'Social class, linguistic codes and grammatical elements' (originally published in Language and Speech 5 in 1962), 'Elaborated and restricted codes: their social origins and some consequences' (published in the American Anthropologist in 1964) and 'A socio-linguistic approach to social learning' (originally published in the Penguin Survey of the Social Sciences, edited by J. Gould, 1965). ${ }^{10}$ None of these texts are, however, referenced in either Jensen (1968) or Labov (1970). What may also have happened is that since the concept 'code' was clearly associated with Bernstein by the time Jensen and Labov wrote their texts, they may have used that term erroneously in reference to Bernstein's earlier work. ${ }^{11}$

We wish to argue that the development of Bernstein's code concept saw an attempt to define code in relation to its regulative functions. Indeed, in 1977 Bernstein (1977: 180, emphasis in original) defined code as 'a regulative principle, tacitly acquired, which integrates relevant meanings, the forms of their realization and their evoking contexts'. This is significant, since it clearly highlights the role played by different codes in orienting individuals to both what they find significant in specific contexts and how they communicate this. In the 'Postscript' to Gahagan \& Gahagan (1970), Bernstein is intent on clarifying that the regulative function of code means that different codes relate not to ability, in the sense that children who grow up with a restricted code are not able to produce the structures children with an elaborated code do, but instead to use (Bernstein 1970b: 115-116). In other words, children with a restricted code will in certain contexts be less likely to orient to and produce the kinds of meanings children with an elaborated code will, since there is a restriction on the contexts which prompt the use of a linguistic variant (or surface feature):

Thus the concept restricted code does not specify that linguistic expressions of uncertainty, syntactic markers of the logical distribution of meaning, will never be used or are not available, only that (and 'only' is critical) there is a restriction on the contexts in which they are used.

(Bernstein 1970b: 116)

Attempting progressively to differentiate between code as an underlying regulator of communication and the surface features produced in actual 
communication, which come to be known as speech variants (Bernstein 1971), Bernstein argues that certain contexts tend to evoke certain linguistic expressions and this evocation will be contingent upon the underlying code:

In this sense, code elaboration entails greater selection and combination from the same linguistic resources than does code restriction. Because the code is restricted it does not mean that elaborated speech variants never occur; because the code is elaborated it does not mean that linguistically restricted speech variants never occur.

(Bernstein 1970b: 117, emphasis in original)

It is not only in this 'Postscript' that Bernstein makes such arguments. In an article entitled 'Social class, language and socialization', originally published in 1971 (and then as chapter nine of the first volume of Class, Codes and Control), Bernstein similarly maintains that "[t]his does not mean that working-class children do not have access to such expressions, but that the eliciting speech context did not provoke them" (1971: 179, emphasis in original). ${ }^{12}$

Such examples are important. They show that the term 'restricted' should not be equated with a deficit on the part of the children, if by this we mean that children with a restricted code are not able to produce those surface variants indicative of an underlying elaborated code. What Bernstein attempts to make manifest through such examples is the relative likelihood of certain contexts prompting a particular orientation to meaning in relation to a code of social behaviour. In his own terminology,

different social structures may generate different speech systems or linguistic codes. The latter entail for the individual specific principles of choice which regulate the selections he [sic] makes from the totality of options represented by a given language. The principles of choice originally elicit, progressively strengthen and finally stabilise the planning procedures an individual uses in the preparation of his speech and guide his orientation to the speech of others. What he actually says, from a developmental perspective, transforms him in the act of saying.

(Bernstein 1964: 56, emphasis added)

For Bernstein, children whose underlying code is an elaborated one, tend to be more successful at school by virtue of the compatibility between the requirements of the school and the way such children orient to meaning, both regarding perception and production. In the case of the elaborated code, this orientation to meaning is connected to the explicitness 
of meaning, and defined on a psychological level ${ }^{13}$ in relation to the 'extent to which each facilitates (elaborated code) or inhibits (restricted code) the orientation to symbolize intent in a verbally explicit form' (Bernstein 1971: 77). With respect to explicitness, this notion of 'facilitation' is connected here to 'elaborated' and 'inhibition' to 'restricted', highlighting again that the restriction is not to be taken as indicative of any kind of deficit on the part of the children. Furthermore, the restricted in restricted code can also be connected to a restriction in educational possibilities on the part of children from lower social classes. Since such children tend to achieve worse results at school than children from higher social classes, the likelihood of them being able to choose from a variety of career options after the completion of high school is restricted at the outset. As Bernstein (1971: 4) states in relation to the City Day College pupils he taught from 1954-1960, '[s]chool had given them up many years earlier'.

Finally, Bernstein also emphasizes that the idea is not to replace a public language with a formal one (and by implication a restricted code with an elaborated code). Not only would this constitute an attempt to sever an individual from that which s/he knows (1971: 54), but Bernstein also implies it would be a loss, in the sense that a public language while restricting (in terms of educational possibilities) and while restricted (in terms of the inhibiting of explicitness), 'contains its own aesthetic, a simplicity and directness of expression, emotionally virile, pithy and powerful and a metaphoric range of considerable force and appropriateness' (1971: 54). Furthermore, '[s]ome examples taken from the schools of this country have a beauty which many writers might well envy'. Bernstein's example of the 'gaps between the lines [of poetry being] full of meaning' (cf. section 2) which arise out of the implicit nature of the language structure are testimony to the importance of the unsaid as much as of the said, an idea which links up with theories of contemporary Gricean pragmatics and Relevance Theory. We conclude from this that the notion of restriction in no way indicates a restriction in the communicative potential of either middle-class or working-class children.

In the light of these comments, it is surprising that Labov (1970) accuses Bernstein of being biased against all forms of working-class behaviour and of seeing middle-class language as superior 'in every respect' (cf. section 4). Bernstein was obviously aware of Labov's interpretation of his theory of codes as presented in 'The logic of non-standard English'; in his 1997 article, Bernstein maintains that his theory of codes was 'selectively recontextualized'. It was taken up at a period of intellectual enthusiasm for 'the idealism of competence' in many of the social sciences: 
Indeed, the theory became a means of bestowing ideological purity on those who denounced it. It was, at the time essential to the intellectual field, for I had created almost single-handed a focus for the field's ritual cleansing. In this respect Labov's paper, 'The Logic of NonStandard English' achieved canonical status .... (Bernstein 1997: 47)

For Bernstein, this 'idealism of competence' distracts attention from looking at the social arrangement of power and control and its structuring in society. It is for this reason that he believes that the idealism is 'bought at a price', viz. 'the abstracting of the individual from the analysis and distribution of power and principles of control which selectively specialize modes of realization and their acquisition' (Bernstein 1997: 46).

The disagreement between Bernstein and Labov may well be related to their different academic backgrounds, which also partly explain their dissimilar methodologies. While Labov can be seen as the pioneer of variationist sociolinguistics, interested in language use and structure, Bernstein was a linguistically minded sociologist, whose approach to language was more in line with work done in the sociology of language. Yet they agree that children of certain socio-economic and cultural backgrounds should not be placed at a disadvantage at school on the basis of their language, since linguistic differences should not be seen as deficient from a linguistic point of view. This mixture between agreement and disagreement is brought out clearly when Bernstein states the following:

I agree only with Labov's conclusion: "We see no connection between verbal skill in the speech events characteristic of street culture and success in the school".

The connection between between socio-economic/socio-cultural background and performance at school is still a salient one, and it is to this present-day continuation of a serious social problem that we turn to in our conclusion.

\section{Conclusion: standard and non-standard language use}

We began the introduction to this article with Bernstein's comment that Labov's article has not really been looked at closely. Yet the whole article actually shows that Bernstein's work was also dismissed the minute he was associated with a verbal deficit viewpoint, which he was in variationist sociolinguistic circles with the publication of 'The logic of nonstandard English'. If we look at other forms of sociolinguistics, notably interactional sociolinguistics in the spirit of Gumperz and Hymes, it be- 
comes evident that Bernstein was not dismissed out of hand in other, perhaps less well-known sociolinguistic circles. But the whole thrust of this article is that the time has come for Bernstein to be re-read and rehabilitated for the simple reason that the kinds of educational problem recognised by Bernstein in the late 1950s have by no means disappeared. They have been transformed over the course of the years into the educational problems confronting migrant workers from different parts of the world in first-world countries, ${ }^{14}$ and this is a process which we expect to continue and augment in the wake of a globalising world economy.

One of the sad things about the way in which Bernstein's work has been evaluated since Labov's blunt dismissal of him in 'The logic of nonstandard English' is that the work done by the two scholars in the field of education, looked at in detail, should never be placed at opposite ends of a continuum. Just two references suffice to demonstrate how influential (if not to say misleading) Labov's criticism was and how ingrained certain notions about Bernstein being a deficit theorist have become. The first reference is to a Massachusetts teacher's evaluation of what her Puerto Rican children cannot do linguistically, which Rosina LippiGreen evaluates as follows:

In this second approach, a teacher has effectively summarized all of the conclusions drawn from Bernstein's theories of restricted and elaborated codes: speakers of non-mainstream language don't possess sufficient human language to think or reason [verbal deficit theory, BB \& RJW], and must be helped to overcome these language and cultural handicaps [compensatory education, BB \& RJW]. The fact that Bernstein's theories and the resulting pedagogical innovations based on them were thoroughly and resoundingly debunked as long ago as 1970 with Labov's 'Logic of Non-Standard English' is an indication of how seductive such rhetoric can be in an educational setting. (1997: 111)

We trust that readers of this article can now appreciate our efforts to 'thoroughly and resoundingly' debunk such assumptions as Rosina LippiGreen's - despite the undoubted overall quality of her book. Bernstein did not have any theories which stated that 'speakers of non-mainstream language don't possess sufficient human language to think or reason' nor did he believe in programmes to help them 'overcome these language and cultural handicaps'. The second reference is to the ingrained belief in the German-speaking academic world that Bernstein both founded deficit theory and promoted compensatory education. We requote the quotation from the German version of Wikipedia presented at the beginning of section 2 of this article: 
Basil Bernstein stellte in den 1960-er Jahren die Defizithypothese in der Soziolinguistik auf. Er stellte die Theorie auf, dass die Sprache der Unterschicht defizitär gegenüber der Sprache der Mittelschicht sei.

['Basil Bernstein set up the deficit hypothesis in sociolinguistics during the 1960s. He set up the theory that the language of the lower classes was deficient when compared with the language of the middle class.']

Once again we trust that the reader can now see through this particularly pernicious language myth.

Rather than see Labov and Bernstein as being incompatible with one another, it is much more reasonable to see the one as complementing the other. Both were deeply concerned with social stigmatisation in the school, leading to the under-achievement of children from the lower classes of the social stratum. Both were against compensatory education. Both believed in the creative linguistic potential of working-class children, and at least Bernstein experimented in the classroom in his own creative ways to draw out this creativity. ${ }^{15}$

Labov was concerned to argue that non-standard varieties of English, particularly AAVE or what at that time he called Black English Vernacular, had their own internal structures and could be used for creative language work and logical thought just as easily as Standard English. In fact, he attempts to demonstrate that certain Afro-American middle class speakers are less adept at presenting their logical arguments than are some Afro-American working-class speakers (Labov 1970, 1972). The discrimination focused on by Labov is one of non-standard speakers by standard speakers, and he erroneously assumes Bernstein's restricted code to be equivalent to a non-standard language variety.

As we show in section 5, however, this is most definitely not how Bernstein's restricted code is to be interpreted, although we can understand how Labov made this mistake by taking Bernstein second-hand, as it were, from the work of Jensen. Bernstein's code idea was not even fully developed by the time Labov wrote his 1970 article. A thorough reading of Bernstein's work has led us to the conclusion that his concept of 'code' is to be understood as part of his attempt to grasp the semiosis of social behaviour, and it should be clear that social behaviour automatically entails language behaviour. We also remind readers of what Bernstein himself said about the code concept in 1987:

I certainly would not wish to defend indicators of what was called then 'public language use' but would argue emphatically that it was made abundantly clear and stated that such a framework of communication should not be confused with dialect ..., that in my terms all 
languages and their varieties carried the same potential for producing either of the associated speech forms ....

If 'restricted code' is not to be equated with 'dialect' or any other form of non-standard variety, Labov's criticism and Lippi-Green's assumptions are simply invalid. Because the code concept deals with the relationship between social semiosis and the linguistic forms used for different orientations to meaning in social context, the concept itself applies to any variety of language whatsoever, whether standard or non-standard. The major issue then becomes whether the orientation to meaning in a social context depends on oral or written forms of language, and there is a strong school of thought which argues that there is no such thing as an 'oral standard' in any case (Crowley [1989] 2003; Milroy \& Milroy [1985] 1999; Watts \& Trudgill 2002; Carter \& McCarthy 1995; Bex 2008).

However, if we shift the metaphorical goal-posts slightly and focus more closely on the social process of stigmatisation rather than on restricted and elaborated codes, ${ }^{16}$ i.e. if we take Labov's perspective on under-achievement in the schools, the differences between an 'imagined' standard oral language and other linguistic varieties (regardless of whether they are non-standard varieties or other 'imagined' standards) are certainly open to those processes. For example, the idea that to be a good Swiss one must have a command of standard German is nothing short of absurdity in a country in which the German-speaking population values the dialects more highly than the standard. Yet this is what migrants to the German-speaking part of Switzerland are expected to do in order to 'integrate' into Swiss society (cf. Bundesamt für Migration: http://www.bfm.admin.ch/bfm/de/home/themen/integration.html. Accessed 18.12.08).

To conclude, we wish to argue that the under-achievement of workingclass children in the Britain of the 1950s and 1960s may well have been attributable, at least in part, to discriminatory processes based on an 'imagined' standard vs. non-standard dichotomy. The codes were crucial in cementing these processes, but not because they were equivalent to that dichotomy. We also need to point out here, that Labov is right to argue for the logic of African American vernacular, especially as a counter to the view being propagated by certain educational psychologists, such as Jensen that speakers of AAVE have no language. Furthermore, Labov's article managed to revolutionise sociolinguistic methodology regarding interview techniques, and he successfully highlighted the significant role interviews play in influencing the performances (both the what and the how) of the interviewees. 
If displaying different orientations to meaning in social context is equivalent to the performances produced by subjects in various types of social context, then it might be here that we should look for the ultimate significance of Bernstein's code theory. It is not so much the language used in doing what one does but the way in which one does it - the latter, of course very often constraining the former. But however code theory is finally interpreted, we believe that Labov would surely not disagree with Bernstein's assessment of the central task of the school:

The school's central task as I see it is to offer all children the possibility of exploring the boundaries of man's [sic] consciousness in such a way that the boundaries are not experienced as a prison, but as a tension between the known and the possible.

(Bernstein 1970b: 117)

Regardless of whether or not code theory can be put to some use in helping to solve this task, there is still enough in Bernstein's overall work to warrant a critical and serious reevaluation of it. Much depends on researchers' willingness to admit that they were wrong in accusing Bernstein of proposing a verbal deficit theory and to grant that a concerted effort to tackle the present-day problems of language and education can benefit from rehabilitating him.

\section{Notes}

1. The focus of social inequality in Britain in the 1950s and 1960s was on social class differences, although that focus has shifted considerably since the 1970s towards ethnic differences. The principal focus of social inequality in the USA has always been ethnic differences.

2. We are referring here largely to first-world countries (the USA and Canada, most countries in western Europe, Australia, and recently even Japan) in which one of the current major problems within the school-system is the influx of immigrant children. Most immigrant families tend to be situated socially at the lower end of social class scale and are not conversant with the language in use in schools. As we shall see in section 4, the problem was slightly different in the 1960 s where working-class children generally used non-standard forms of the standard language mandatory for education in the national school system(s).

3. Here Bernstein is referring to the papers in the first volume of Class, Codes and Control (1971).

4. The references in this article are to the published version of the talk in the first volume of Class, Codes and Control (1971).

5. The pronoun we in this quotation is not inclusive of Bernstein but is a reference to the whole academic community.

6. References to both the originally published 1959 and 1960 articles are to the versions published in the first volume of Class, Codes and Control (1971).

7. The term 'socio-cultural deficit' refers to a deficit in understanding, or even accepting, the cultural conditions imposed by the institution 'school', since those conditions are imposed socially from 'above', i.e. they are socio-culturally constructed by the middle-classes. 
8. Bernstein's affiliation with Halliday and the clear influence that Halliday had on Bernstein regarding the regulative contexts of socialisation warrant the assumption of a connection between Bernstein's views in the late 1970s and 1980s and those of Halliday on the link between language and social semiosis (cf. Halliday 1978).

9. All of these texts, except for 'Elaborated and restricted codes: their social origins and some consequences' (Bernstein 1964) can be found in the first volume of Class, Codes and Control (1971).

10. It is unlikely that Bernstein's talk delivered to the Work Conference of the Teacher's College, Columbia University in 1970 influenced Jensen (1968) or Labov (1970). While Jensen (1968) had already been published by the time Bernstein held the talk, it further seems that Labov's 'The logic of nonstandard English' was presented in March 1970, while Bernstein seems to have held the talk in July 1970.

11. As Bolander (this volume) points out, this is what Ris seems to have done for the Swiss-German situation.

12. Again, the reference is to the version published in the first volume of Class, Codes and Control (1971).

13. Bernstein also attempts to define the code in relation to language such that codes are defined on a linguistic level and a psychological level. On a linguistic level, they relate to the predictability of the syntactic makeup of an individual's production of language (see Bernstein 1971: 76-77).

14. This category can no longer be restricted to what are traditionally and loosely referred to as 'the West'. Japan, Australia and New Zealand can be counted as targets of migration, as can countries which are difficult to define as 'first-world' or 'third-world', e.g. South Africa, countries in the Middle east such as Qatar, Bahrain and the United Arab Emirates, or which were once part of the so-called 'second-world' (the former communist bloc comprising Eastern Europe and China). Here the major host country at present is the Russian Federation. The problem of migration is not only one of population movement between countries. Internal migration can also lead to similar kinds of educational problem involving language and identity, e.g. China (cf. Jie Wong \& Blommaert 2009).

15. Labov's work on AAVE also had and continues to have clear practical applications for the classroom.

16. We freely admit here that the terms themselves are not particularly well chosen and almost invite the kind of erroneous criticism they have received.

\section{References}

Atkinson, Paul (1985). Language, structure and reproduction: An introduction to the sociology of Basil Bernstein. London: Methuen.

Bereiter, C., S. Engelman, J. Osborn \& P. Reidford (1966). An academically oriented pre-school for culturally disadvantaged children. In F. M. Hechinger (ed.), Preschool education today, 105-137. New York: Doubleday.

Bernstein, Basil (1964). Elaborated and restricted codes: Their social origins and some consequences. American Anthropologist 66(6), Part 2: The ethnography of communication. 55-69.

- (1970a). Foreword. In Dennis Gahagan \& Georgina Gahagan. 1970. Talk reform: Explorations in language for infant school children, vii-x. London: Routledge and Kegan Paul.

- (1970b). Postscript. In Dennis Gahagan \& Georgina Gahagan. 1970. Talk reform: Explorations in language for infant school children, 115-117. London: Routledge and Kegan Paul. 
- (1971). Class, codes and control, Volume 1. Theoretical studies towards a sociology of language. New York: Schocken Books.

- (1977). Class, codes and control Volume 3. Towards a theory of educational transmissions (Revised Edition). London: Routledge and Kegan Paul.

- (1981). Codes, modalities and the process of cultural reproduction - a model. Language in Society 10(3). 327-63.

- (1987). Social problems, theoretical approaches and research results. In Ulrich Ammon, Norbert Dittmar \& Klaus Mattheier (eds.), Sociolinguistics. Soziolinguistik. An international handbook of the science of language and society. Volume 1, 563-579. Berlin: Walter de Gruyter.

- (1990). Class, codes and control. Volume 4. The structuring of pedagogic discourse London: Routledge.

- (1997). Sociolinguistics: A personal view. In Christina Paulston \& Richard Tucker (eds.), The early days of sociolinguistics: Memories and reflections. Austin, Texas: Summer Institute of Linguistics, Inc., 43-53.

Bex, Tony (2008). 'Standard English', discourse grammars and English language teaching. In Miriam Locher \& Jürg Strässler (eds.), Standards and norms in the English language, 221-238. Berlin: Mouton de Gruyter.

Bex, Tony \& Richard Watts (eds.) (1999). Standard English. The widening debate. London: Routledge.

Bourdieu, Pierre (1991). Language and symbolic power. Edited and with an introduction by John B. Thompson. Cambridge: Polity Press.

Carter, Ronald \& Michael McCarthy (1995). Grammar and the spoken language. Applied Linguistics 16(2). 140-158.

Crowley, Tony [1989] (2003). Standard English and the politics of language. Basingstoke: Palgrave Macmillan.

Deutsch, Martin, Irwin Katz \& Arthur Jensen (eds.). Social class, race, and psychological development. New York: Holt.

Dittmar, Norbert (1976). Sociolinguistics: A critical survey and application. Translated by Peter Sand. London: Edward Arnold.

Gahagan, Dennis \& Georgina Gahagan (1970). Talk reform: Explorations in language for infant school children. London: Routledge and Kegan Paul.

Halliday. Michael A. K. (1978). Language as social semiotic: The social interpretation of language and meaning. London: Edward Arnold.

Jensen, Arthur (1968). Social class and verbal learning. In Martin Deutsch, Irwin Katz \& Arthur Jensen (eds.), Social class, race, and psychological development, 115-174. New York: Holt.

Labov, William (1970). The logic of non-standard English. In James E. Alatis (ed.), $20^{\text {th }}$ Annual Round Table. Linguistics and the teaching of Standard English to speakers of other languages or dialects. Georgetown: Georgetown University Press, 145.

- (1972a). Language in the inner city. Studies in the Black English Vernacular. Philadelphia: University of Pennsylvania Press.

- (1972b). Academic ignorance and black intelligence. The Atlantic Online, June.

Linke, Angelika, Markus Nussbaumer \& Paul R. Portmann (1991). Studienbuch Linguistik. Tübingen: Max Niemeyer Verlag.

Lippi-Green, Rosina (1997). English with an accent: Language, ideology, and discrimination in the United States. London: Routledge.

Locher, Miriam \& Jürg Strässler (eds.) (2008). Standards and norms in the English language. Berlin: Mouton de Gruyter.

Martín Rojo, Luisa, Esther Alcalá Recuerda, Aitana Garí Pérez, Laura Mijares, $\mathbf{M}^{\mathrm{a}}$ Ángeles Rodríguez \& Inmaculada Sierra Rodríguez (2003). ¿Asimilar o integrar?: Dilemas ante el multilingüismo en las aulas, Madrid: CIDE-MEC. 
Milner, Esther (1951). A study of the relationship between reading readiness in grade one school children and patterns of parent-child interaction. Child Development 22. $95-112$.

Milroy, James \& Lesley Milroy [1985] (1999). Authority in language: Investigating Standard English. London: Routledge.

Neuland, Eva (1988). Kompensatorische/emanzipatorische Spracherziehung. In Ulrich Ammon, Norbert Dittmar \& Klaus J. Mattheier (eds.), Sociolinguistics. Soziolinguistik. An international handbook of the science of language and society. Volume 2, 1734-1744. Berlin: Walter de Gruyter.

Oevermann, Ulrich (1972). Sprache und soziale Herkunft. Ein Beitrag zur Analyse schichtenspezifischer Sozialisationsprozesse und ihrer Bedeutung für den Schulerfolg. Frankfurt am Main: Suhrkamp.

Watts, Richard (2003). Politeness. Cambridge: Cambridge University Press.

Watts, Richard \& Peter Trudgill (eds.) (2002). Alternative histories of English. London \& New York: Routledge.

Wikipedia. http://www.wikipedia.org/. (14.12.08).

Wong, Jie \& Jan Blommaert (2009). Space, scale and accents: Constructing migrant identity in Beijing. Multilingua 28(1). 1-23.

www.ourdocuments.gov. The Civil Rights Act. http://www.ourdocuments.gov/doc large_image.php?doc $=97$ Accessed 18. 12.08.

Brook Bolander is an assistant for English Linguistics at the University of Basle, Switzerland. Her research interests are in sociolinguistics, computer-mediated communication and discourse analysis. She is currently working on a $\mathrm{PhD}$ project on the negotiation of power in blogs.

Address for correspondence: Englisches Seminar, Nadelberg 6, CH-4051 Basel. Brook. Bolander@unibas.ch

Richard J. Watts is emeritus professor of English Linguistics at the University of Berne. He is currently editor of Multilingua and of the book series Language, Power and Social Process, both published by Mouton de Gruyter. His publications include Power in family discourse (Mouton, 1991), Politeness (Cambridge University Press, 2003), Standard English: The widening debate (Routledge, edited with Tony Bex), Alternative histories of English (Routledge, edited with Peter Trudgill), Die fünfte Landessprache?: Englisch in der Schweiz (vdf Zürich, edited with Heather Murray). He has written widely on politeness, English in Switzerland, English historical linguistics, discourse analysis and pragmatics.

Address for correspondence: Seestrandweg 97, 3235 Erlach, Switzerland. watts@ens. unibe.ch 